\title{
THE ROLE OF THE MALE PARENT IN THE REPRODUCTION OF RUBUS
}

\author{
D. L. JENNINGS, D. L. CRAIG * and P. B. TOPHAM \\ Scottish Horticultural Research Institute, Invergowrie, Dundee
}

Received I5.vi.66

\section{INTRODUCTION}

Rubus species vary greatly in the degree to which they reproduce sexually. Pollination is essential for fruit development and the pollen parent plays a part in determining the proportions of sexual and nonsexual individuals in a progeny. Crane (I94I) considered that asexual ovules were produced by apospory in certain European blackberries, and that the proportions of sexual and asexual ovules were fixed within certain limits before pollination: to explain variation in the proportion of hybrids which occurred when different pollen parents were used, he suggested that there were differences in compatibility between the hybrid embryos and the maternal tissues. There are several instances where the use of diploid pollen parent has given a higher proportion of sexual progeny than a parent of higher ploidy: Crane and Thomas (1939), for example, found that the octoploid Rubus vitifolius gave only sexual (pentaploid) progeny when pollinated by diploid raspberry, but produced apomictic progeny as well when tetraploid raspberry pollen was used; and Dowrick ( 1966 ) noticed that $R$. laciniatus gave 36.8 per cent. of sexual progeny with diploid blackberry pollen, I $9^{\cdot 2}$ per cent. with tetraploid blackberry pollen and none with pollens of higher ploidy. In diploid raspberries ( $R$. idaeus) reproduction is normally entirely sexual, but unreduced gametes are frequently formed here too, and Keep (1958) concluded that their chance of survival compared with reduced gametes was apparently determined by the male parent.

Recently, Dowrick suggested that apomixis is not important in the reproduction of Rubus, since the production of maternal-like progeny seemed to depend solely upon the formation of reduced egg cells in $R$. caesius, $R$. calvatus and $R$. laciniatus. His observations are apparently supported by those of Christen (1950) working with $R$. caesius and Markarian and Olmo (1959) with $R$. procerus, but Pratt and Einsett (1955) found both aposporic and sexual embryo sacs in certain American blackberries. Dowrick suggested that maternal-like progeny developed from reduced egg cells following either restitution at the first division of the egg or "fusion" of nuclei within the embryo sac ("automixis"). The consequences of either of these processes is that the tetraploid species concerned are homozygous, though, since they are almost certainly amphidiploids (Bammi, I 965 ), there will be homo-

* Head of Small Fruits Section of Kentville Research Station, Canada Department of Agriculture, Nova Scotia, Canada. This paper is contribution No. 1230 of the Canada Department of Agriculture. 
zygosity only between the chromosomes of each of the two complexes which together make up the tetraploid. Variability among matroclinous progenies of blackberries has previously been attributed to crossing-over at prophase between chromosomes which later form a restitution nucleus during meiosis: recognition of such variability led Crane to use the term sub-sexual to describe reproduction in Rubus, but this term is avoided here because of the doubts regarding the occurrence of this meiotic sequence. Seedlings formed with and without the genetic participation of the male nucleus are merely described as hybrid and non-hybrid respectively.

This paper examines more closely the role of the male parent in the reproductive behaviour of $R$. laciniatus, a tetraploid blackberry known to be a facultative pseudogamous apomict, and that of Merton Thornless, a tetraploid blackberry previously considered to be entirely sexual.

\section{MATERIAL AND METHODS}

Pot-grown plants of tatraploid cut-leaf blackberry ( $R$. laciniatus) and tetraploid Merton Thornless blackberry (a cultivar derived from Rubus rusticanus $\times R$. thyrsiger) were brought into flower in June 1964 under glasshouse conditions at Dundee. Plants of the following were brought into flower at the same time for use as pollen parents, but only the raspberry parents were used for crossing with Merton Thornless:-

I. The diploid red raspberries Malling Jewel and the East Malling Seedling $69 / 139$.

2. Autotetraploid forms of these two raspberries obtained from somatic mutations.

3. The diploid blackberry $R$. rusticanus.

4. The tetraploid blackberries Brazos (a cultivar derived from crossing between $R$. rubrisetus and $R$. strigosus), Merton Early (a cultivar of $R$. nitidioides) and Merton Thornless.

5. The hexaploid blackberry $R$. magnificus and a smooth-caned form of the hexaploid Loganberry (an allopolyploid derived from crossing between $R$. ursinus and raspberry).

Eight randomly-chosen laterals were used for each cross, and seven to nine days after pollination the developing fruits on one-half of the laterals were brushed with a 50 p.p.m. aqueous solution containing equal parts of betanapthoxyacetic acid and parachlorophenoxyacetic acid. Such treatments have been found to improve drupelet set in blackberries (Marth and Meader, I944; Zelinski and Garren, r954).

The nutlets were extracted from the ripe fruit using an Atomix blender, classified as large or small and counted. They were germinated at Kentville, Nova Scotia, following pre-treatment with sulphuric acid and calcium hypochlorite (Jennings and Tulloch, 1965) and storage at $40^{\circ} \mathrm{C}$. for 14 weeks before sowing. Samples of up to 15 large and 15 small nutlets from each treatment in the $R$. laciniatus series were dissected and seed and embryo sizes measured.

A total of 1924 seedlings were grown for at least five months, by which time they were about 12 in. high. They were then classified as hybrid or non-hybrid using the recessive characters "cut-leaf" and "spinelessness" in the progenies from $R$. laciniatus and Morton Thornless respectively. Chromosome counts were made from root-tip squashes from 645 of the 697 hybrids and, where sufficient plants were available, from at least five non-hybrid seedlings from each cross. The root tips were first pre-treated with 8-hydroxyquinoline, fixed in acetic alcohol and stained in lactopropionic orcein (Haskell and Paterson, 1964). 


\section{FRUIT SET, NUTLET AND SEED DEVELOPMENT AND GERMINATION}

In the crosses where $R$. laciniatus was the maternal parent, hardly any fruits were set when either of the diploid or tetraploid raspberries or the loganberry were used as pollen parents without auxin, but

TABLE I

Fruit set and nutlet development following pollination of $\mathrm{R}$ nbus laciniatus with different pollen parents, with and without subsequent auxin treatment

\begin{tabular}{|c|c|c|c|c|c|c|c|c|}
\hline \multirow{2}{*}{ Pollen parent } & \multicolumn{2}{|c|}{$\begin{array}{l}\text { No. flowers } \\
\text { pollinated }\end{array}$} & \multicolumn{2}{|c|}{$\begin{array}{l}\text { No. fruits } \\
\text { obtained }\end{array}$} & \multicolumn{2}{|c|}{$\begin{array}{c}\text { No. large } \\
\text { nutlets/fruit }\end{array}$} & \multicolumn{2}{|c|}{$\begin{array}{c}\text { No. small } \\
\text { nutlets/fruit }\end{array}$} \\
\hline & $\begin{array}{l}\text { No } \\
\text { aux. }\end{array}$ & Aux.* & $\begin{array}{l}\text { No } \\
\text { aux. }\end{array}$ & Aux. & $\begin{array}{l}\text { No } \\
\text { aux. }\end{array}$ & Aux. & $\begin{array}{l}\text { No } \\
\text { aux. }\end{array}$ & Aux. \\
\hline $2 \times M, 60 / 130$ & 20 & 23 & 2 & 7 & $6 \cdot 0$ & $2 \cdot 4$ & 0 & $24 \cdot 6$ \\
\hline 2XM. Jewel & 24 & 35 & 2 & 26 & $1 \cdot 5$ & $7 \cdot 9$ & o & $43 \cdot 7$ \\
\hline $4 \mathrm{XM} \cdot 69 / 139$ & 22 & 26 & 2 & 18 & $2 \cdot 0$ & $z \cdot 9$ & $\mathbf{0}$ & 53.9 \\
\hline $4 \mathrm{XM}$. Jewel & 17 & 26 & I & 20 & $I \cdot O$ & $7 \cdot 0$ & $1 \cdot 9$ & 44.9 \\
\hline $2 \mathrm{X} R$. rusticanus & 30 & 30 & 30 & 28 & $23 \cdot 3$ & $21 \cdot 6$ & $2 \cdot 4$ & $33 \cdot I$ \\
\hline $4 \mathrm{XBrazos}$ & 21 & 26 & 19 & 26 & 12.4 & $13 \cdot 3$ & $1 \cdot 6$ & 33.5 \\
\hline $4 \mathrm{XM}$. Thornless & 24 & 30 & 22 & 27 & $15 \cdot 8$ & I $2 \cdot 9$ & 3.4 & 33.8 \\
\hline 4X. Early & 22 & $3 I$ & 22 & 29 & $3^{1} \cdot 9$ & $33: 2$ & $3 \cdot 3$ & $16 \cdot 7$ \\
\hline $6 \mathrm{Xl}$ oganberry & 20 & 29 & 3 & I5 & $9 \cdot 7$ & $2 \cdot 3$ & 0.3 & $3^{8 \cdot 0}$ \\
\hline 6XR. magnificus & 24 & 23 & 24 & 23 & $18 \cdot 9$ & I $7 \cdot 3$ & $3 \cdot 3$ & $29 \cdot 2$ \\
\hline
\end{tabular}

* Auxin $=50$ p.p.m. aqueous solution of equal parts betanaphthoxyacetic acid and parachlorphenoxyacetic acid applied 7-9 days after pollination.

TABLE 2

Fruit set and nutlet development following pollination of Merton Thornless with different pollen parents, with and without subsequent auxin treatment

\begin{tabular}{|c|c|c|c|c|c|c|c|c|}
\hline \multirow{2}{*}{ Pollen parent } & \multicolumn{2}{|c|}{$\begin{array}{l}\text { No. flowers } \\
\text { pollinated }\end{array}$} & \multicolumn{2}{|c|}{$\begin{array}{l}\text { No. fruits } \\
\text { obtained }\end{array}$} & \multicolumn{2}{|c|}{$\begin{array}{c}\text { No. large } \\
\text { nutlets/fruit }\end{array}$} & \multicolumn{2}{|c|}{$\begin{array}{c}\text { No. small } \\
\text { nutlets/fruit }\end{array}$} \\
\hline & $\begin{array}{l}\text { No } \\
\text { aux. }\end{array}$ & Aux.* & $\begin{array}{l}\text { No } \\
\text { aux. }\end{array}$ & Aux. & $\begin{array}{l}\text { No } \\
\text { aux. }\end{array}$ & Aux. & $\begin{array}{l}\text { No } \\
\text { aux. }\end{array}$ & Aux. \\
\hline 2XM. 69/139 & 16 & I 3 & 14 & 13 & $12 \cdot 6$ & $14: 3$ & $9 \cdot 3$ & $3^{8 \cdot 4}$ \\
\hline 2XM. Jewel & I 3 & I3 & I 3 & I 3 & $10 \cdot 0$ & $8 \cdot 9$ & 14.5 & $3^{6 \cdot 2}$ \\
\hline $4 X M .69 / 139$ & 10 & I 5 & IO & 15 & 16.8 & 3.3 & $8 \cdot 6$ & 43.3 \\
\hline $4 \mathrm{XM}$. Jewel & 6 & I3 & 6 & I 2 & $15 \cdot 2$ & $I I \cdot I$ & $2 \cdot 3$ & $3^{-2}$ \\
\hline
\end{tabular}

* See footnote to table 1 .

application of auxin greatly improved the set. Fruit set was good in the remaining crosses of this series and also in those with Merton Thornless. No improvement in the regularity of the drupelets was obtained by auxin treatment (tables I and 2), and in most cases drupelet size within the fruit was exceedingly variable (Plate I $(l)$. Nutlet development, on the other hand, was strongly influenced by 
auxin treatment in all the crosses: the number of small nutlets per fruit was greatly increased regardless of pollen or maternal parent, the only exception being the cross Merton Thornless $\times$ tetraploid $M$. Jewel. The number of large seeds per fruit varied considerably too, but here the pollen parent had the most influence; the number was particularly low in the crosses mentioned which gave poor fruit set, but variations also occurred between the fruits from crosses with different blackberries. Except for the crosses between $R$. laciniatus and the two forms of Malling Jewel, there was a slight tendency for auxin treatment to decrease the number of large nutlets per fruit, but this reduction was far exceeded by the increase in number of small

TABLE 3

The average sizes of seed, embryo and endosperm, the rate of fruit maturation and the per cent. seed germination in crosses with $\mathbf{R}$. laciniatus

\begin{tabular}{|c|c|c|c|c|c|c|}
\hline \multirow{2}{*}{\multicolumn{2}{|c|}{ Pollen parent }} & \multicolumn{3}{|c|}{$\begin{array}{c}\text { Average sizes } \\
\left(\text { length } \times \text { breadth in } \mathrm{mm} .{ }^{2}\right) \text { of }\end{array}$} & \multirow{2}{*}{$\begin{array}{c}\text { No. days } \\
\text { from } \\
\text { pollination } \\
\text { to fruit ripe }\end{array}$} & \multirow{2}{*}{$\begin{array}{l}\text { Percentage } \\
\text { seed } \\
\text { germina- } \\
\text { tion }\end{array}$} \\
\hline & & Seed & Embryo & Endosperm* & & \\
\hline 2XM. $69 / 139$ & $\stackrel{\mathbf{A} \dagger}{\mathrm{C}}$ & $3 \cdot 94$ & $3 \cdot 19$ & $\stackrel{0.75}{-}$ & $\begin{array}{l}56 \\
53\end{array}$ & $\begin{array}{l}57 \cdot 1 \\
9 ! \cdot 7\end{array}$ \\
\hline 2XM. Jewel & $\stackrel{\mathrm{A}}{\mathrm{C}}$ & $4 \cdot 18$ & $3 \cdot 08$ & $1 \cdot 10$ & $\begin{array}{l}62 \\
62\end{array}$ & $\begin{array}{c}38 \div 7 \\
0\end{array}$ \\
\hline 4XM. $69 / 139$ & $\stackrel{\mathrm{A}}{\mathrm{C}}$ & $\stackrel{3 \cdot 88}{-}$ & $3 \cdot 16$ & $\underline{0 \cdot 72}$ & $\underline{62}$ & $\begin{array}{l}0 \\
0\end{array}$ \\
\hline R. rusticanus & $\stackrel{A}{\mathrm{C}}$ & $\begin{array}{l}5 \cdot 87 \\
3 \cdot 29\end{array}$ & $\begin{array}{l}3 \cdot 38 \\
3 \cdot 23\end{array}$ & $\begin{array}{l}2.49 \\
0.47\end{array}$ & $\begin{array}{l}53 \\
49\end{array}$ & $\begin{array}{l}26 \cdot 3 \\
38 \cdot 6\end{array}$ \\
\hline Brazos & $\begin{array}{l}\mathrm{A} \\
\mathrm{C}\end{array}$ & $\begin{array}{l}3 \cdot 79 \\
3 \cdot 5^{8}\end{array}$ & $\begin{array}{l}2 \cdot 89 \\
3 \cdot 23\end{array}$ & $\begin{array}{l}0 \cdot 90 \\
0 \cdot 36\end{array}$ & $\begin{array}{l}59 \\
55\end{array}$ & $\begin{array}{l}27.4 \\
28.9\end{array}$ \\
\hline Merton Thornless & $\begin{array}{l}\mathrm{A} \\
\mathrm{C}\end{array}$ & $\begin{array}{l}4 \cdot 19 \\
3 \cdot 68\end{array}$ & $\begin{array}{l}3 \cdot 51 \\
3 \cdot 02\end{array}$ & $\begin{array}{l}0 \cdot 67 \\
0 \cdot 65\end{array}$ & $\begin{array}{l}52 \\
50\end{array}$ & $\begin{array}{l}26 \cdot 8 \\
30 \cdot 9\end{array}$ \\
\hline Merton Early & $\begin{array}{l}\mathrm{A} \\
\mathbf{C}\end{array}$ & $\begin{array}{l}4 \cdot 07 \\
3 \cdot 30\end{array}$ & $\begin{array}{l}3 \cdot 37 \\
2 \cdot 72\end{array}$ & $\begin{array}{l}0.70 \\
0.58\end{array}$ & $\begin{array}{l}48 \\
48\end{array}$ & $\begin{array}{l}29 \cdot 1 \\
36 \cdot 7\end{array}$ \\
\hline Loganberry & $\begin{array}{l}\mathrm{A} \\
\mathrm{C}\end{array}$ & 3.94 & $3 \cdot 36$ & $\underline{0.59}$ & $\begin{array}{l}65 \\
52\end{array}$ & $\underset{0}{50 \cdot 0}$ \\
\hline R. magnificus & $\begin{array}{l}\mathrm{A} \\
\mathrm{C}\end{array}$ & $\begin{array}{l}4 \cdot 17 \\
4 \cdot 22\end{array}$ & $\begin{array}{l}3 \cdot 25 \\
3 \cdot 43\end{array}$ & $\begin{array}{l}0.92 \\
0.80\end{array}$ & $\begin{array}{l}57 \\
54\end{array}$ & $\begin{array}{l}35 \cdot 4 \\
44^{\circ} \cdot 8\end{array}$ \\
\hline
\end{tabular}

* Endosperm size is estimated from the difference between seed and embryo sizes.

$\dagger \mathrm{A}$ and $\mathrm{C}$ are auxin treated and control respectively. 
ones, which must therefore have been attained by prevention of drupelet abortion. By reason of the higher number of drupelets present in the auxin-treated fruit the average weight of treated compared to untreated fruit was increased by $37^{\circ} 8$ per cent. in the crosses with $R$. laciniatus and by $45^{\circ}$ I per cent. in those with Merton Thornless.

Dissection of the small nutlets from each cross showed them all to be devoid of contents. Dissections of large nutlets were done only for the $R$. laciniatus series. They showed (table 3 ) that auxin increased the size of the endosperm relative to that in the controls by amounts ranging from I per cent. (Merton Thornless) to 530 per cent. ( $R$. rusticanus). In the untreated series, endosperm size was slightly augmented in the crosses with the two tetraploid Merton varieties compared with the one with diploid $R$. rusticanus, and increased further in the cross with hexaploid $R$. magnificus. Neither auxin nor pollen type had much effect on embryo size, but auxin delayed fruit maturation by a few days. Auxin aided the development of viable nutlets in some crosses, but in most crosses the nutlets from treated fruits had a lower capacity to germinate.

\section{SEGREGATION OF HYBRID AND NON-HYBRID SEEDLINGS}

The segregation of hybrid and non-hybrid seedlings in crosses with R. laciniatus and Merton Thornless is given in tables 4 and 5 respectively.

TABLE 4

Proportions of haploids, non-hybrids and hybrids obtained in progenies of Rubus laciniatus

\begin{tabular}{|c|c|c|c|c|c|c|c|c|}
\hline \multirow[b]{2}{*}{ Pollen parent } & \multicolumn{4}{|c|}{ Auxin treated fruits } & \multicolumn{4}{|c|}{ Untreated fruits } \\
\hline & $\begin{array}{l}\text { Total } \\
\text { seed- } \\
\text { lings }\end{array}$ & $\begin{array}{c}\text { Per- } \\
\text { centage } \\
\text { hap- } \\
\text { loids }\end{array}$ & $\begin{array}{l}\text { Per- } \\
\text { centage } \\
\text { non- } \\
\text { hybrids }\end{array}$ & $\begin{array}{l}\text { Per- } \\
\text { centage } \\
\text { hybrids }\end{array}$ & $\begin{array}{l}\text { Total } \\
\text { seed- } \\
\text { lings }\end{array}$ & $\begin{array}{c}\text { Per- } \\
\text { centage } \\
\text { hap- } \\
\text { loids }\end{array}$ & $\begin{array}{c}\text { Per- } \\
\text { centage } \\
\text { non- } \\
\text { hybrids }\end{array}$ & $\begin{array}{l}\text { Per- } \\
\text { centage } \\
\text { hybrids }\end{array}$ \\
\hline 2XM. 69/1 39 & 4 & o & $75^{\circ} \cdot 0$ & $25 \cdot 9$ & I I & 0 & $45^{\circ} 4$ & $54 \cdot 5$ \\
\hline $2 \mathrm{XM}$. Jewel & 76 & 0 & $76 \cdot 3$ & $23 \cdot 6$ & o & - & & -0 \\
\hline 4 XM. $69 / 139$ & o & 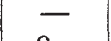 & $7=0$ & 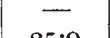 & o & - & - & - \\
\hline $4 \mathrm{XM}$. Jewel & 4 & $\begin{array}{l}0 \\
0\end{array}$ & $75^{\circ} 0$ & $\begin{array}{l}25^{\circ} \mathrm{O} \\
50 \cdot 8\end{array}$ & $\begin{array}{r}\circ \\
268\end{array}$ & $\overline{0.7}$ & $-\overline{5}$ & $-\overline{0}$ \\
\hline $\begin{array}{l}2 \times K \cdot \text { rusticanus } \\
4 \mathrm{XBrazos}\end{array}$ & $\begin{array}{r}57 \\
89\end{array}$ & $\begin{array}{l}0 \\
0\end{array}$ & $\begin{array}{l}40 \cdot 1 \\
52 \cdot 8\end{array}$ & $\begin{array}{l}59^{\circ} \mathrm{O} \\
47^{\circ} \mathrm{I}\end{array}$ & $\begin{array}{r}200 \\
66\end{array}$ & $\begin{array}{l}0.7 \\
1 \cdot 5\end{array}$ & $\begin{array}{l}55.5 \\
60 \cdot 1\end{array}$ & $\begin{array}{l}43^{\circ} 0 \\
37 \cdot 8\end{array}$ \\
\hline $4 \mathrm{XM}$. Thornless & $9 \mathrm{I}$ & 0 & $67 \cdot 0$ & $32 \cdot 9$ & I04 & 0 & $72 \cdot I$ & $27 \cdot 8$ \\
\hline 4XM. Early & 279 & $0 \cdot 3$ & $72 \cdot 0$ & 27.5 & 254 & $0 \cdot 4$ & $64 \cdot 5$ & $35^{\circ} \mathrm{O}$ \\
\hline 6XLoganberry & 12 & 0 & & $4^{1} \cdot 6$ & 0 & 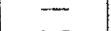 & & \\
\hline $6 \times R$. magnificus & 137 & 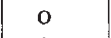 & $80 \cdot 2$ & 19.7 & 200 & 0.5 & $85^{\circ} 6$ & $14 \cdot 0$ \\
\hline Total & 849 & O.I & $65 \cdot \mathrm{I}$ & $34 \cdot 7$ & 903 & 0.5 & 66.8 & $32 \cdot 5$ \\
\hline
\end{tabular}

In the $R$. laciniatus series (table 4 ), chi-square tests show significant differences in the proportions of non-hybrid seedlings produced by the different male parents both with and without auxin treatment. There was a tendency for this proportion to increase with each increase in the ploidy of the male parent and the coefficient of correlation $(+0.596)$ 
TABLE 5

Proportions of non-hybrids and hybrids obtained in progenies of Merton Thornless

\begin{tabular}{|c|c|c|c|c|c|c|}
\hline \multirow[b]{2}{*}{ Pollen parent } & \multicolumn{3}{|c|}{ Auxin treated fruits } & \multicolumn{3}{|c|}{ Untreated fruits } \\
\hline & $\begin{array}{c}\text { Total } \\
\text { seedlings }\end{array}$ & $\begin{array}{c}\text { Percentage } \\
\text { non- } \\
\text { hybrids }\end{array}$ & $\begin{array}{l}\text { Percentage } \\
\text { hybrids }\end{array}$ & $\begin{array}{c}\text { Total } \\
\text { seedlings }\end{array}$ & $\begin{array}{c}\text { Percentage } \\
\text { non- } \\
\text { hybrids }\end{array}$ & $\begin{array}{l}\text { Percentage } \\
\text { hybrids }\end{array}$ \\
\hline $\begin{array}{l}\text { 2XM. 69/139 } \\
\text { 2XM. Jewel } \\
\text { 4XM. 69/139 } \\
\text { 4XM. Jewel } \\
\text { Total }\end{array}$ & $\begin{array}{r}27 \\
26 \\
8 \\
31 \\
92\end{array}$ & $\begin{array}{l}33 \cdot 3 \\
34 \cdot 6 \\
37 \cdot 5 \\
61 \cdot 2 \\
43^{\circ} \cdot 4\end{array}$ & $\begin{array}{l}66 \cdot 6 \\
65 \cdot 3 \\
62 \cdot 5 \\
38 \cdot 7 \\
56 \cdot 5\end{array}$ & $\begin{array}{l}17 \\
23 \\
28 \\
12 \\
80\end{array}$ & $\begin{array}{l}41 \cdot 1 \\
21 \cdot 7 \\
21 \cdot 4 \\
50 \cdot 0 \\
30 \cdot 0\end{array}$ & $\begin{array}{l}58 \cdot 8 \\
78 \cdot 2 \\
78 \cdot 5 \\
50 \cdot 0 \\
70 \cdot 0\end{array}$ \\
\hline
\end{tabular}

between the proportion of non-hybrid seedlings and the ploidy of the male parent is significant with I I degrees of freedom. This relationship is illustrated in fig. I. Differences in ploidy between the pollen parents

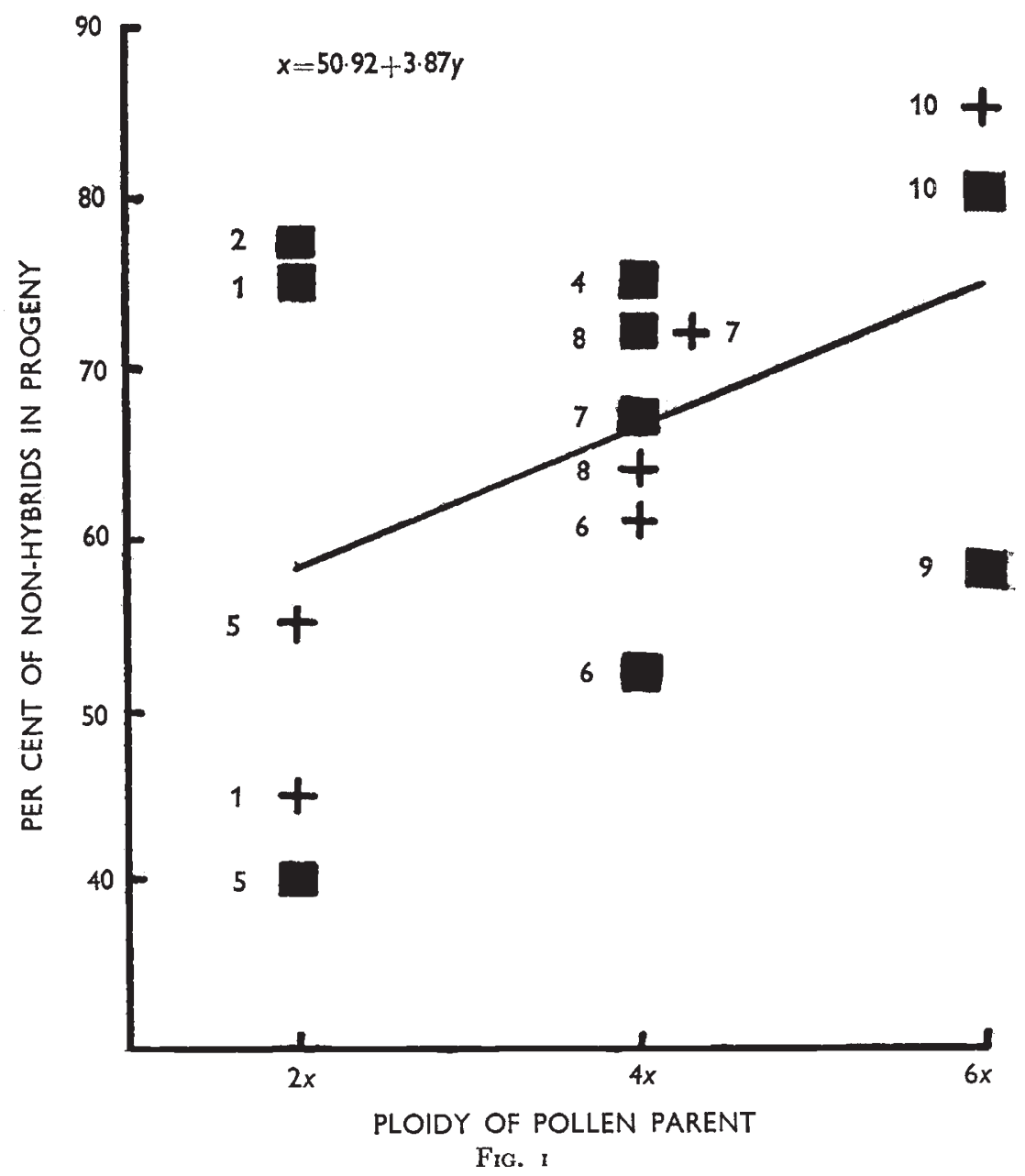


clearly do not account for all the differences, however; for example, the segregation following pollination with diploid raspberry pollen was closer to that from pollination with tetraploid blackberries than that with the diploid blackberry. Chi-square tests also show that auxin treatment decreased the proportions of non-hybrid seedlings in the crosses with $R$. rusticanus and $R$. magnificus. The results for the other families showed no consistent trend and there was no overall effect. due to auxin.

TABLE 6

Chromosome numbers of hybrid seedlings obtained from pollinating

R. laciniatus with different Rubus pollens

\begin{tabular}{|c|c|c|c|c|c|c|c|c|c|c|c|c|c|}
\hline \multirow{2}{*}{\multicolumn{2}{|c|}{ Pollen parent }} & \multicolumn{12}{|c|}{ Number of hybrids with chromosome numbers of } \\
\hline & & 21 & 22 & 23 & 25 & 27 & 28 & 29 & $3^{2}$ & 35 & $4^{2}$ & 49 & $5^{6}$ \\
\hline $2 X M .69 / 139$ & $\begin{array}{l}\mathrm{A}^{*} \\
\mathrm{C} \dagger\end{array}$ & 3 & & & & & $\begin{array}{l}1 \\
3\end{array}$ & & & & & & \\
\hline${ }_{2} \mathrm{XM}$. Jewel & $\stackrel{\mathrm{A}}{\mathrm{C}}$ & 3 & & & & & 12 & & & 1 & 2 & & \\
\hline 4 XM. $69 / 139$ & $\begin{array}{l}\mathrm{A} \\
\mathrm{C}\end{array}$ & & & & & & & & & & & & \\
\hline $4 \mathrm{XM}$. Jewel & A & & & & & 1 & & & & & & & \\
\hline $2 \mathrm{X} R$. rusticanus & $\underset{\mathrm{C}}{\mathrm{A}}$ & $\begin{array}{l}76 \\
88\end{array}$ & $\begin{array}{l}2 \\
2\end{array}$ & $\begin{array}{l}2 \\
3\end{array}$ & 1 & 1 & $\begin{array}{r}6 \\
11\end{array}$ & & & $\begin{array}{l}7 \\
7\end{array}$ & & & \\
\hline 4 XBrazos & $\stackrel{\text { A }}{\mathrm{C}}$ & $\begin{array}{l}2 \\
3\end{array}$ & & 1 & & & $\begin{array}{l}32 \\
17\end{array}$ & & & 4 & $\begin{array}{l}1 \\
2\end{array}$ & & \\
\hline 4 XMerton Thornless & $\underset{\mathrm{C}}{\mathrm{A}}$ & $\mathrm{I}$ & & & & & $\begin{array}{l}22 \\
24\end{array}$ & & & I & $\begin{array}{l}4 \\
1\end{array}$ & & \\
\hline${ }_{4} \mathrm{XMerton}$ Early & $\stackrel{\mathrm{A}}{\mathrm{C}}$ & & & & & & $\begin{array}{l}32 \\
65\end{array}$ & & I & & $\begin{array}{l}42 \\
23\end{array}$ & & I \\
\hline 6XLoganberry & $\stackrel{\mathrm{A}}{\mathrm{C}}$ & & & & & & 4 & & & & & & \\
\hline $6 \mathrm{X} R$. magnificus & $\underset{\mathrm{C}}{\mathrm{A}}$ & & & & & & $\begin{array}{r}7 \\
14\end{array}$ & 1 & & $\begin{array}{l}6 \\
6\end{array}$ & $\begin{array}{l}3 \\
2\end{array}$ & $\begin{array}{l}6 \\
3\end{array}$ & \\
\hline Totals & & 176 & 4 & 6 & 1 & 2 & 250 & 1 & 1 & 33 & 80 & 9 & I \\
\hline
\end{tabular}

* Auxin treated.

$\uparrow$ Control. 
In the Merton Thornless series untreated with auxin, neither variety nor ploidy made any overall difference to the kind of segregation, but there was a significant interaction between variety and ploidy, larger proportions of hybrids resulting from the pollinations with diploid Malling Jewel and tetraploid 69/139. However, when auxin was applied, $69 / 139$ pollen had the same effect as that of Malling Jewel, and thus the overall effect due to ploidy was significant, with higher proportions of hybrids segregating when diploid pollens were used.

Sixty-four non-hybrid seedlings from the $R$. laciniatus series had the expected number of 28 chromosomes, but among 39 non-hybrid seedlings from the Merton Thornless series three had 21 chromosomes. These occurred in the cross with diploid Malling Jewel. Counts on 645 hybrid seedlings from the two sets of crosses (tables 6 and 7) show

TABLE 7

Chromosome numbers of hybrid seedlings obtained from pollinating Merton Thornless with different Rubus pollens

\begin{tabular}{|c|c|c|c|c|c|c|}
\hline \multirow{2}{*}{\multicolumn{2}{|c|}{ Pollen parent }} & \multicolumn{5}{|c|}{ Number of hybrids with chromosome numbers of } \\
\hline & & 21 & 28 & 29 & 30 & 42 \\
\hline 2XM. $69 / 139$ & $\stackrel{\mathrm{A}^{*}}{\mathrm{C}^{\prime}}$ & & $\begin{array}{r}\mathrm{II} \\
2\end{array}$ & & & \\
\hline 2XM. Jewel & $\underset{\mathrm{C}}{\mathrm{A}}$ & $\begin{array}{l}8 \\
6\end{array}$ & $\begin{array}{l}2 \\
9\end{array}$ & $\mathrm{I}$ & & \\
\hline 4 XM. $69 / 139$ & $\stackrel{\mathrm{A}}{\mathrm{C}}$ & & $\begin{array}{r}5 \\
18\end{array}$ & 2 & & 2 \\
\hline 4XM. Jewel & $\underset{\mathrm{C}}{\mathrm{A}}$ & & $\begin{array}{l}9 \\
6\end{array}$ & & 1 & \\
\hline Totals & & 14 & 62 & 3 & 1 & 2 \\
\hline
\end{tabular}

that unreduced or " diploidised" gametes frequently participated in the formation of viable embryos. Since the cut-leaf character is highly recessive, the probable genetic make-up of many of the plants can be guessed. For example, for the cross tetraploid $R$. laciniatus $\times$ diploid Malling Jewel, the leaf illustrated in plate $I(c)$ suggests fusion between a diploid egg and a haploid pollen nucleus; the one in plate I $(e)$ suggests fusion between a tetraploid egg and a haploid pollen nucleus and that in plate $I(f)$ suggests fusion between a tetraploid egg and an unreduced diploid pollen nucleus. Similar interpretations can be 
suggested for the leaves illustrated in plate $I(g)-(j)$, which are from seedlings from crosses between $R$. laciniatus and a blackberry. In addition, six maternal haploids, i 8 aneuploids and several abnormal forms such as "spongy leaf" were found. It is notable that a high proportion of these occurred in the cross with $R$. rusticanus.

The cross $R$. laciniatus $\times$ Merton Early is the only one where application of auxin resulted in a different array of hybrid plants as revealed by chromosome counts. Of 88 hybrid seedlings derived from untreated fruits of this cross, 65 ( 74 per cent.) had 28 or fewer chromosomes and 23 had more than 28; for 76 seedlings derived from auxin-treated fruits, the numbers were 32 ( 42 per cent.) and 44 respectively. This difference is statistically significant $\left(\alpha^{2}=\mathrm{I} 7.02 ; \mathrm{P}<0.00 \mathrm{I}\right)$. This cross gave a particularly good set of large nutlets, but it was also exceptional in that auxin may have increased the overall proportion of non-hybrid seedlings too $\left(a^{2}=3.44 ; \mathrm{P}<0.05\right)$. It is interesting that the treatment which possibly increased the proportion of nonhybrids should also have increased the proportion of hybrid seedlings with high chromosome numbers.

\section{DISCUSSION}

One of the most striking features of this experiment was the exceedingly low fertility of the two blackberries. With $R$. laciniatus, the most productive cross averaged 54.7 nutlets per fruit when auxin was applied (table I), and yet only an average of $2 \mathrm{I} \cdot 6$ of these were large and contained an embryo. Even fewer developed in the other crosses, and usually considerably fewer than 40 per cent. of these germinated (table 3). The number of seedlings whose genotype was identified was thus only a small fraction of the potential number of embryos which could have been formed, and since there was never any indication that pollination was inadequate, the low numbers of nutlets per fruit must have been due to failures in their development. The different segregations obtained from different kinds of pollination suggest that there were different selective forces acting upon hybrid and non-hybrid embryos in different crosses and that these were largely determined by the genotype of the male parent.

If, as Dowrick (I 966 ) suggests, diploidised egg cells are formed by restitution at the first division of the egg, it follows that they would have an octoploid fusion nucleus and they might in consequence have a stronger capacity for endosperm development. The large increases in endosperm size associated with the use of high-ploidy pollen support this idea, though the evidence does not indicate whether these increases are to be attributed to increasing participation of diploidised embryo sacs or to greater nuclear contributions from the high-ploidy pollens. However, if larger endosperms are in fact characteristic of diploidised embryo sacs, it is important to consider how this would improve their chances of survival in crosses with high-ploidy pollen. The enhanced 
survival of the non-hybrids following auxin treatment may also be considered in this context, since the auxin effect on segregation was large only when its effect on endosperm size was also substantial. Auxin did not increase embryo survival, but the reduction in number of large nutlets and increase in number of small ones suggest that it impeded the development of strongly growing nutlets and improved that of weaker ones.

These results all suggest that the developmental failures in the seed may have causes similar to those ascribed for many other crosses between parents differing in ploidy. In such crosses, reviewed by Stebbins (1958), it is usual for crosses in which the female parent has a higher ploidy than the male to produce a greater proportion of viable embryos than the reciprocal case. The identity of the maternal tissue which determines the response is not known with certainty, but von Wangenheim (1961; 1962), working with Solanum and Oenothera, has produced strong evidence favouring explanations based upon the genetic constitution of the endosperm, and not implicating other maternal tissues. To explain why crosses between Nasturtium species of like ploidy showed the same kind of embryo and seed abortion as that found in intraspecies crosses involving plants of different ploidy, Howard (1947) used the concept of the "genetic strength" of a genome: a diploid species was said to have higher genetic strength than another if it behaved as if it were of higher ploidy in crosses with it, and, as with crosses between plants of different ploidy within the species, the more successful direction of crossing is the one where the pollen has the lower genetic strength. Valentine (1956) also found this concept useful when discussing the results of crosses between Primula species. Put into these terms, the diploid, tetraploid and hexaploid male parents used for the $R$. laciniatus crosses represent a series of increasing genetic strength, and variations in genetic strength between species of like ploidy are also to be expected. If it is the endosperm which determines the genetic strength of the embryo sacs in $R$. laciniatus too, it would follow that those with large endosperms-thought to be the diploidised ones-would have a greater chance of survival in crosses with species whose genetic strength is greater than that of $R$. laciniatus, and those from reduced embryo sacs would be favoured in crosses with species of lower genetic strength. Thus it is possible that the only features which distinguish the breeding behaviour of $R$. laciniatus from that of sexual $R u b i$ are (i) a weak capacity for endosperm development, which gives a relatively low genetic strength to its sexual embryo sacs, and (ii) its amphidiploid origin, which restricts segregation in its nonhybrid progeny. The results can be explained without inplicating apomixis, though Rubus species in general seem to have an exceptionally strong tendency to produce diploidised embryo sacs. Cases where unreduced embryo sacs function only when the pollen parent has a higher ploidy than the maternal parent are known from other genera where apomixis is not a normal aspect of breeding behaviour: for 
example in Solanum (von Wangenheim, I96 I) and in maize (Alexander, I957), though in these cases the egg nuclei are always fertilised.

The crosses between $R$. laciniatus and diploid raspberry pollen gave relatively high proportions of non-hybrids. The reason for this is not clear. Possibly raspberries have greater genetic strength than blackberries, but the parents were so distantly related and the drupelet-set so low that more serious incompatibilities may be present. Merton Thornless was a more successful parent in this respect (tables I and 2). It appeared to have more "tolerance" of raspberry pollen and, possibly for this reason, it showed no clear benefit from auxin treatment either in respect of fruit set or numbers of large nutlets per fruit.

The surprising feature of the Merton Thornless result is the number of non-hybrids obtained, since the variety has previously been regarded as entirely sexual. Neither Haskell and Hill (I96I) nor Scott, Darrow and Ink (1957) found any non-hybrid seedlings in crosses between this cultivar and other blackberries, but the discovery that non-hybrid seedlings can occur in some circumstances offers an alternative explanation for several genetical results obtained with the variety or its close relatives. For example, the fact that parents related to Merton Thornless gave genetic ratios nearer to $20 \cdot 78$ : I than $35^{\circ}$ I for disomic segregation at the $S$ locus led Crane and Darlington (1932) and later Haskell and Hill ( $196 \mathrm{I}$ ) to conclude that chromatid and not chromosome segregation was occurring. However, if diploidisation of the eggs occasionally occurred without fertilisation, the ratio of dominant to recessive phenotypes formed by gametic segregation would be $5:$ I, and the process could lead to an excess of recessives, thereby confusing assessments of the amount of chromatid segregation. The results of these two studies with crosses among European blackberries conflict with those of Scott et al. (I957), with derivatives of Merton Thornless crossed with American blackberries. In the latter work, the $F_{2}$ ratios were either $35:$ I or else the proportion of recessives was significantly less. Scott et al. suggested that the gene might be linked with a lethal, and it is interesting to speculate that the "lethal" might have influenced the interaction between the embryo and its surrounding seed tissues. It is conceivable that such a gene could have opposite consequences to seed development in varieties differing in the stimulating power of their pollen or in the tolerance of their maternal response.

Production of non-hybrid progeny could be exploited in plant breeding, because, if such progeny are the result of diploidisation occurring in the ways suggested by Dowrick, they would be expected to be relatively homozygous and could possibly be used to attain homozygosity more rapidly than by selfing. In many amphidiploid varieties homozygosity within the two chromosome complexes may not result in much loss of vigour, since genetic diversity between the complexes would still be present. Possibly progenies from selfing such homozygous material would resemble the parent sufficiently for the variety to be propagated in this way, thereby eliminating non-seed- 
borne viruses. The occasional triploid among the non-hybrid Merton Thornless progeny suggests the occurrence of such meiotic irregularities as " complement fractionation ", described for certain other blackberries by Bammi (1965), but these were not frequent.

\section{SUMMARY}

I. Plants of Rubus laciniatus, a pseudogamous apomictic blackberry, and of Merton Thornless, previously regarded as being entirely sexual, were pollinated with different male parents, and auxin was applied to a half of the fruits seven to nine days after pollination.

2. In some crosses with $R$. laciniatus auxin application improved the development of fruits but in others the average numbers of large nutlets per fruit and their germinability were slightly reduced.

3. In the $R$. laciniatus series, the proportion of non-hybrids differed with different male parents and was positively correlated with the ploidy of the male parent. In two of the crosses auxin treatment significantly increased the proportion of hybrids. Unreduced or diploidised gametes frequently functioned successfully, and in one cross auxin increased the production of hybrids with high chromosome number. Many non-hybrids occurred in the Merton Thornless series also, and here too their proportion was influenced by the male parent used.

4. The survival of different arrays of genotypes in different crosses was explained by postulating that the selection pressure on the embryo sac is determined by its relative compatibility with the genetic constitution of the pollen parent. The concept of the "genetic strength" of a genome is of value in explaining the results.

Acknowledgment.-We are indebted to Mr. L. J. Eaton of Dalhousie University, Halifax, Nova Scotia, for assistance with the cytology and to Miss B. Tulloch of the Scottish Horticultural Research Institute for technical assistance.

\section{REFERENCES}

ALEXANDER, D. E. 195\%. The genetic induction of autotetraploidy: A proposal for its use in corn breeding. Agron. Fn., 49, 40-43.

ваммI, R. K. 1965. "Complement fractionation" in a natural hybrid between Rubus procerus Muell. and $R$. laciniatus Willd. Nature, Lond., $208,608$.

CHRISTEN, H. R. 1950. Untersuchungen über die Embryologie pseudogamer und sexueller Rubusarten. Ber. Schweiz. Bot. Ges., 6o, 153-198.

CRANe, M. B. 194I. Pomology department. Rep. Fohn Innes hort. Instn. for 1940, 4-6. CRANE, M. B., AND DARLington, C. D. 1932. Chromatid segregation in tetraploid Rubus. Nature, Lond., I29, 869.

CRANE, M. B., AND THOMAS, P. T. 1939. Segregation in asexual (apomictic) offspring in Rubus. Nature, Lond., 143, 684.

DowrICK, G. J. 1966. Breeding systems in tetraploid Rubus species. Genet. Res., 7, 245-253.

HASKELL, G., AND HILL, J. I961. Segregation in tetraploid blackberries. Heredity, เ6, 354. 


\section{Plate I}

(a) Leaf of tetraploid $R$. laciniatus $2 \mathrm{n}=28$.

(b) Leaf of diploid $R$. laciniatus $2 \mathrm{n}=\mathrm{I} 4$.

$(c)-(f)$ Leaves from hybrid progeny of $R$. laciniatus $(4 \mathrm{n}) \times$ Malling Jewel $(2 \mathrm{n}) ; 2 \mathrm{n}=2 \mathrm{I}, 28,35,42$.

$(g)-(j)$ Leaves from hybrid progeny of $R$. laciniatus $(4 \mathrm{n}) \times$ Brazos; $2 \mathrm{n}=2 \mathrm{I}, 28,35,42$.

(k) Perfect fruit of $R$. laciniatus $(4 \mathrm{n})$ obtained parthenocarpically following treatment with 500 p.p.m. gibberellic acid.

(l) Typical fruit of $R$. laciniatus $(4 \mathrm{n})$ with irregular drupelet size obtained by self pollination. 


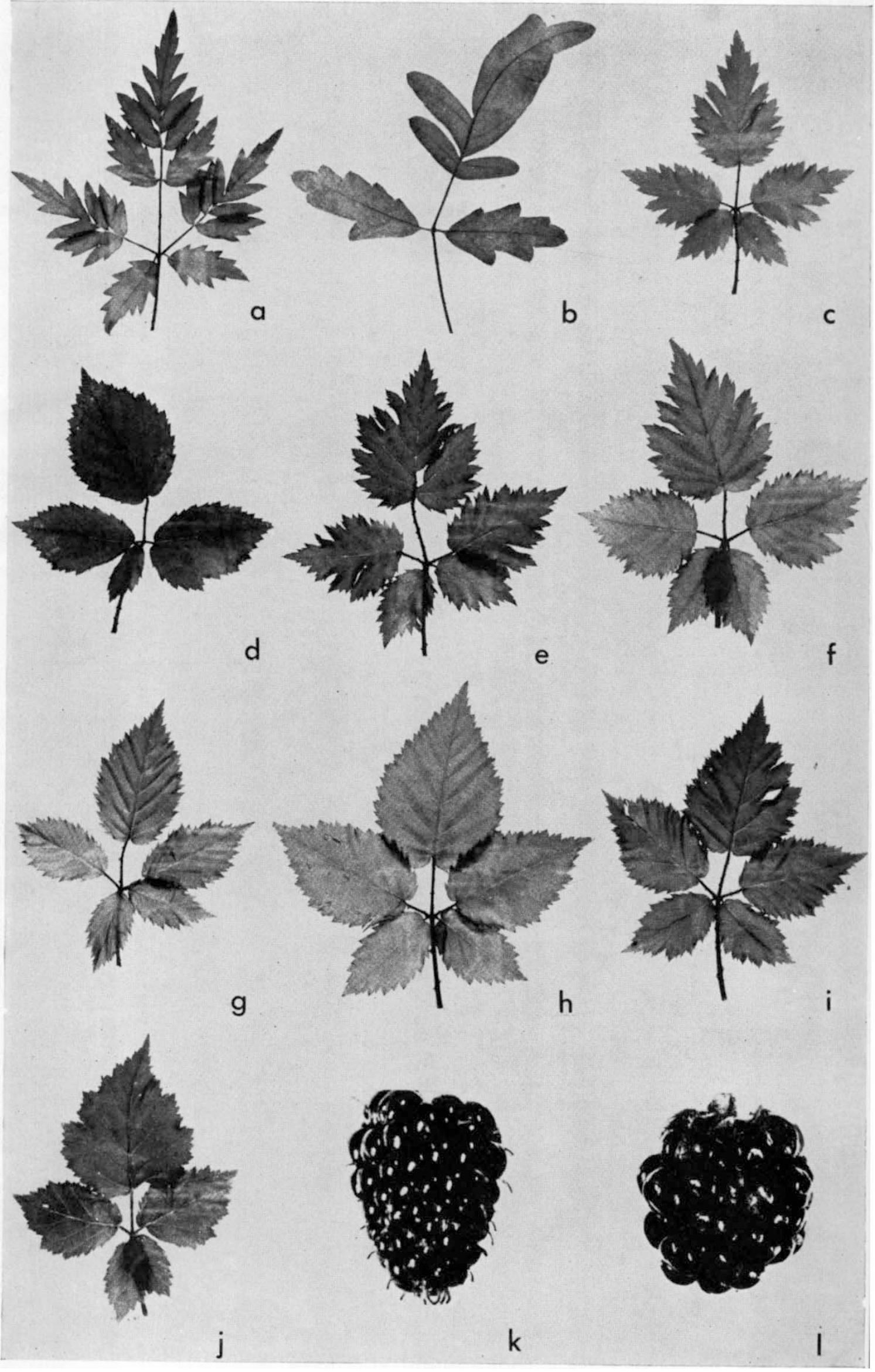


HASKell, G., AND PATERSON, E. B. 1965. Quick preparation of corolla chromosomes from flower buds. Nature, Lond., 203, 673-674.

HOWARD, H. W. 1947. Seed size in crosses between diploid and autotetraploid $\mathcal{N}$ asturtium officinale and allotetraploid $\mathcal{N}$. uniseriatum. $\mathcal{F}$. Genet., 48,111 -1 18.

JENNings, D. L., AND TUlLOGH, B. M. M. 1964. Studies on factors which promote germination of raspberry seeds. Fn. Exp. Bot., 16, 329-340.

KEEP, E. 1958. Cytological notes. Rept. E. Malling Res. Sta. for 1957, 76 .

MARTH, P. C., AND MEADER, E. M. 1944. Influence of growth-regulating chemicals on blackberry fruit development. Proc. Amer. Soc. hort. Sci., 45, 293-299.

MARKaRIan, D., AND OLMO, H. P. I959. Cytogenetics of Rubus. I. Reproductive behaviour of $R$. procerus Muell. $7 n$. Heredity, 50, 13 $1-136$.

PRATT, C., AND EINSET, J. 1955. Development of the embryo sac in some American blackberries. Amer. Fn. Bot., 42, 637-645.

SCOTT, D. H., DARROW, G. M., AND INK, D. P. I957. Merton Thornless as a parent in breeding thornless blackberries. Proc. Amer. Soc. hort. Sci., 69, 268-277.

STEBBINS, G. L. 1958. The inviability, weakness and sterility of interspecific hybrids. Advances in Genetics, 9, 147-215.

VAlentine, D. H. 1956. Studies on British Primulas. V. The inheritance of seed compatibility. New Phytol., 55, 305-318.

von WANGENheim, к. M. 1961. Zur Ursache der Abortion von Samenanlagen in Diploid-Polyploid-Kreuzungen. I. Die Chromosomenzahlen von mutterlichen Gewebe, Endosperm und Embryo. Z. Pfanzenzüchtung, 46, I3-19.

von WANGENHEIM, x. M. I962. Zur Ursache der Abortion von Samenanlagen in Diploid-Polyploid-Kreuzungen. II. Unterschiedliche Differenzierung von Endospermen mit gleichem Genom. Z. Vererbungslehre, 93, 319-334.

ZIELINSKI, Q. B., GARREN, R. ANNEN, and, C. J. 1954. Effects of parachlorophenoxyacetic acid and betanaphthoxyacetic acid on increasing fruit size in Thornless Evergreen blackberries. Proc. Amer. Soc. hort. Sci., 63, 182-1 88. 